\title{
Global collaborative networks on meta-analyses of randomized trials published in high impact factor medical journals: a social network analysis
}

\author{
Ferrán Catalá-López ${ }^{1,2^{*}}$, Adolfo Alonso-Arroyo ${ }^{3,4}$, Brian Hutton ${ }^{5}$, Rafael Aleixandre-Benavent ${ }^{3}$ and David Moher ${ }^{5}$
}

\begin{abstract}
Background: Research collaboration contributes to the advancement of knowledge by exploiting the results of scientific efforts more efficiently, but the global patterns of collaboration on meta-analysis are unknown. The purpose of this research was to describe and characterize the global collaborative patterns in meta-analyses of randomized trials published in high impact factor medical journals over the past three decades.

Methods: This was a cross-sectional, social network analysis. We searched PubMed for relevant meta-analyses of randomized trials published up to December 2012. We selected meta-analyses (including at least randomized trials as primary evidence source) published in the top seven high impact factor general medical journals (according to Journal Citation Reports 2011): The New England Journal of Medicine, The Lancet, the BMJ, JAMA, Annals of Internal Medicine, Archives of Internal Medicine (now renamed JAMA Internal Medicine), and PLoS Medicine. Opinion articles, conceptual papers, narrative reviews, reviews without meta-analysis, reviews of reviews, and other study designs were excluded.

Results: Overall, we included 736 meta-analyses, in which 3,178 authors, 891 institutions, and 51 countries participated. The BMJ was the journal that published the greatest number of articles (39\%), followed by The Lancet (18\%), JAMA (15\%) and the Archives of Internal Medicine (15\%). The USA, the UK, and Canada headed the absolute global productivity ranking in number of papers. The 64 authors and the 39 institutions with the highest publication rates were identified. We also found 82 clusters of authors (one group with 55 members and one group with 54 members) and 19 clusters of institutions (one major group with 76 members). The most prolific authors were mainly affiliated with the University of Oxford (UK), McMaster University (Canada), and the University of Bern (Switzerland).
\end{abstract}

Conclusions: Our analysis identified networks of authors, institutions and countries publishing meta-analyses of randomized trials in high impact medical journals. This valuable information may be used to strengthen scientific capacity for collaboration and to help to promote a global agenda for future research of excellence.

Keywords: Authorship, Evidence-based medicine, Meta-analysis, Randomized controlled trial, Scientific collaboration, Social network analysis

\section{Background}

The past decades have seen the establishment of evidence synthesis, particularly systematic reviews and meta-analyses, as a key component of evidence based medicine (EBM) $[1,2]$. Meta-analyses of randomized trials have become more widely accepted by clinicians, researchers and policy makers as a useful tool to critically assess the totality of

\footnotetext{
* Correspondence: ferran_catala@hotmail.com

'Division of Pharmacoepidemiology and Pharmacovigilance, Spanish Medicines and Healthcare Products Agency (AEMPS), Madrid, Spain

${ }^{2}$ Fundación Instituto de Investigación en Servicios de Salud, Valencia, Spain Full list of author information is available at the end of the article
}

evidence in a research question. When performed well and reported completely, incorporating explicit and detailed methods and results, such studies produce information that can have undoubtedly major, immediate effects on medical practice, research agendas and the establishment of healthcare policies.

Important milestones that may have encouraged research in this field, from the point of view of scientific publications and institutional development of EBM [1-4], include the creation of international research groups, centers, and consortia (such as the Centre for Evidence Based Medicine and 
The Cochrane Collaboration in the 1990s) in addition to groups developing reporting guidelines to ensure articles contain all essential information, such as QUOROM (Quality of Reporting of Meta-analyses) [5] and, more recently, PRISMA (Preferred Reporting Items for Systematic Reviews and Meta-Analyses) [6].

Global health challenges require research collaboration and multi-lateral programs on a global scale, owing to the nature and magnitude of the public health problems. Noteworthy examples include major environmental, political, and social determinants of health, as well as complex and changing clinical issues related to the conditions and risk factors that cause the highest burden of disease around the world [7-9]. Despite continuous efforts of individual scientists and institutions to remedy deficiencies in healthcare effectiveness and safety, multiple gaps and disparities remain. Research collaboration contributes to the advancement of knowledge by exploiting the results of scientific efforts more efficiently, but the global patterns of collaboration on meta-analysis are unknown. Given that metaanalyses can provide high-quality clinical evidence regarding the robustness of the effects of healthcare interventions to inform medical practice, there is an urgent need to evaluate and promote scientific activity and growth in the field of EBM [4,10-12].

Social network analysis [13], the study of structure derived from the regularities in the patterning of relationships between social entities (which might be people or organizations), is grounded in the assessment of empirical data, and can provide an appropriate approach to identify top scientists and researchers, groups of excellence, and leading institutions. It also offers information to assess the citation patterns among papers within a specialty [14], to identify gaps in the evidence from scientific research [15], and to understand the structure and nature of relationships and interactions within a scientific community that collaborate to better achieve common or compatible goals $[13,16]$.

This study aimed to describe and characterize global collaborative patterns with regard to the conduct of metaanalyses of randomized trials published over the past three decades in high impact factor medical journals, by applying techniques from social network analysis.

\section{Methods}

\section{Design and sample}

In December 2012, we searched for reports of metaanalyses of randomized trials that were indexed in PubMed and published in one of the top seven high impact general medical journals, as identified in 2011, based on an impact factor of at least 10 (subject categories 'Medicine, General \& Internal' of Journal Citation Reports, Thomson Reuters): The New England Journal of Medicine (NEJM), The Lancet, the British Medical Journal (BM), the Journal of the
American Medical Association (JAMA), Annals of Internal Medicine, Archives of Internal Medicine (now renamed JAMA Internal Medicine) and PLoS Medicine. Specifically, the following terms were used for PubMed: ('meta-analysis'[Publication Type] OR 'meta-analysis as topic' [MeSH Terms] OR 'meta-analysis'[All Fields]) AND ('randomized controlled trial'[Publication Type] OR 'randomized controlled trials as topic'[MeSH Terms] OR 'randomized controlled trial'[All Fields]) AND ('Lancet'[Journal] OR 'N Engl J Med'[Journal] OR 'JAMA'[Journal] OR 'Br Med J'[Journal] OR 'Br Med J (Clin Res Ed)'[Journal] OR 'BMJ'[Journal] OR 'PLoS Med'[Journal] OR 'Ann Intern Med'[Journal] OR 'Arch Intern Med'[Journal]) AND (hasabstract[text] AND 'humans'[MeSH Terms]). We also performed complementary hand-searches and reviewed references of identified eligible reports to identify additional meta-analyses.

We included two types of articles from the eligible journals: original research reports and reviews (both incorporating meta-analyses of randomized trials). Editorials, commentaries, and other opinion articles were excluded. We also excluded conceptual papers, literature (narrative) reviews, reviews of reviews, meta-analysis of observational studies not considering randomized trials, single randomized trials, and other study designs (such as cost-effectiveness analyses and epidemiological studies).

For the purposes of this study, we selected all articles published in English and indexed in PubMed between January 1985 and December 2012. One researcher with expertise in evidence synthesis (FC-L) screened the titles and abstracts, and identified all potentially eligible articles. The same researcher excluded the articles not meeting the pre-specified criteria.

\section{Data extraction}

For each included paper, we extracted information on the year of publication, the journal title, and the authors' names, institutional affiliation(s), and country of origin. This information was downloaded online through the Science Citation Index-Expanded (SCI-E) Web of Knowledge platform version 5, in April 2013. The Web of Knowledge platform is a database that contains all the above information, including the full addresses of all authors of every paper. We also used the SCI-E to determine the extent to which each study had been cited in the scientific peer-review literature using the 'times cited' number (that is, the number of times a publication has been cited by other publications). A process of standardization was conducted to bring together the different names of a particular author or institution. Specifically, one researcher (AA-A) checked the names by which an individual author appeared in two or more different forms (for example, 'Gordon Guyatt' or 'Gordon H Guyatt'), using coincidence in that author's place(s) of work as the basic criterion for normalization (for example, McMaster University, Canada). 
In the case of institutions, we unified the different variants to match the name recorded in public directories of institutions. Similarly, given that institutional names in many records included two or more institutions (for example, university hospitals, research centers and academic institutions), we proceeded to distinguish between these names by recording all variations of any individual macroinstitution as could be identified for each bibliographic record (for example, for the institutional address 'Reproductive Medicine Unit, Department of Obstetrics \& Gynaecology, University of Adelaide, Queen Elizabeth Hospital, Australia', the standardization approach was to present 'University of Adelaide, Australia' separately from 'Queen Elizabeth Hospital, Australia'). With all this information, we constructed a Microsoft Access database.

\section{Data analysis}

In this paper, we use the term 'co-authorship' to refer to joint authorship of a scientific paper by at least two individuals, and the term 'institutional collaboration' to refer to joint authorship by different institutions. 'Intensity of collaboration or threshold' refers to the number used to form clusters of authors and institutions (that is, the frequency of co-authorship between pairs of authors or of collaboration between institutions), and reflects a criterion to label identifiable clusters as research groups. Collaboration between authors (or institutions) was portrayed by calculating the number of papers, names, signatures and collaborations, the index of signatures per paper or collaboration index (which is the mean number of signatures per paper), and the index of authors per paper (mean number of authors per paper, considering only the different authors). A summary box with definitions of each of the measurements of collaboration is provided in the supplementary material (see Additional file 1: 'Definitions of collaborative measurements').

To construct co-authorship networks, we identified all combinations of pairs of authors for each paper. The number of co-authorships for each paper is related to the number of authors as is equal to

$$
\frac{m !}{(m-n) ! n !}
$$

where $m$ is the number of individual authors and $n$ the number of elements in the groups constructed. Once co-authorship was quantified, we further established an a posteriori threshold of two or more collaborations between pairs of authors, in order to reduce the number of nodes and links that would prevent a clear view of the network, and thus center the analysis on the more intense co-authorship relationships. The same approach was applied to institutional and country authorship to construct the network of collaborations, although in this case, we applied an a posteriori threshold of three or more papers signed in co-authorship. The productivity and patterns of collaboration by author, institution and country were analyzed.

We used PAJEK [17], a software package for large network analysis that is free for non-commercial use, to analyze indicators and construct social networks.

\section{Results}

\section{Number of meta-analyses}

The PubMed search generated 804 records. Following screening of abstracts and full text articles, 724 publications were retained, and 12 additional publications were added from complementary searches of reference lists, thereby yielding a final sample of 736 included meta-analyses. The process of study selection is presented in Figure 1.

\section{General characteristics of the sample}

The $B M J$ published the largest number of articles $(\mathrm{n}=289$; $39 \%)$, followed by The Lancet $(\mathrm{n}=132 ; 18 \%), J A M A(\mathrm{n}=$ $113 ; 15 \%)$ and the Archives of Internal Medicine ( $\mathrm{n}=112$; $15 \%)$. Overall, 736 meta-analyses received 130,644 citations, of which 37,930 citations (29\%) corresponded to BMJ, 34 $911(27 \%)$ to The Lancet and 25,273 (19\%) to JAMA. The number of publications increased exponentially over the study period (Table 1). Approximately three-quarters of the meta-analyses were reported during the most recent decade.

The included meta-analyses had a median of 5 authors, although 41 (6\%) were single authored (Table 1). More than a quarter (214 [29\%]) of the first authors were from the USA, with three countries (the USA, the UK and Canada) accounting for more than two-thirds of the meta-analyses published during the period of analysis (Table 1).

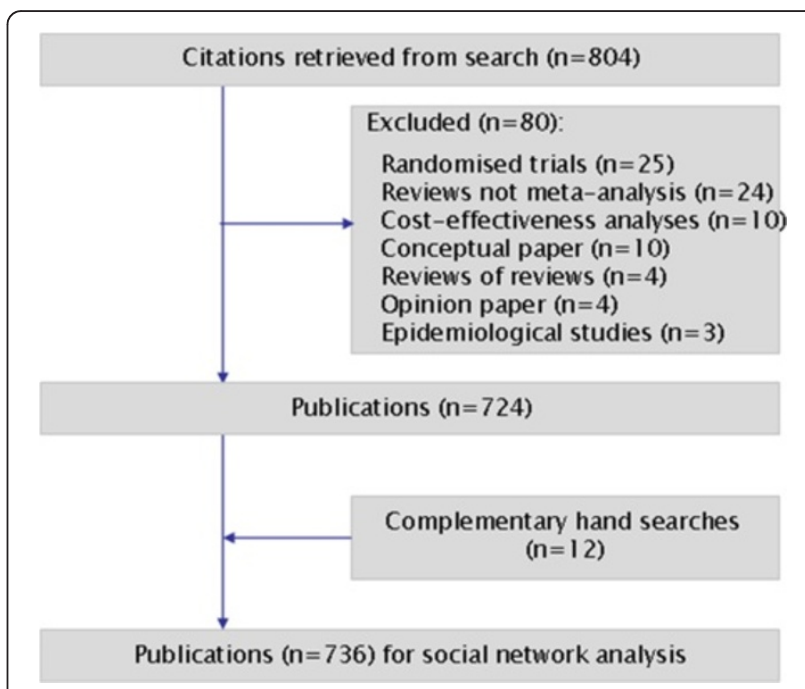

Figure 1 Selection of publications. Flow chart. 
Table 1 General characteristics of the sample of study

\begin{tabular}{|c|c|}
\hline Characteristic & Number (\%) \\
\hline Total number of articles & $736(100)$ \\
\hline \multicolumn{2}{|l|}{ Articles per journal ${ }^{a}$} \\
\hline$B M J$ & $289(39.3)$ \\
\hline The Lancet & $132(17.9)$ \\
\hline JAMA & $113(15.3)$ \\
\hline Arch Intern Med & $112(15.2)$ \\
\hline Ann Intern Med & $70(9.5)$ \\
\hline New Engl J Med & $13(1.8)$ \\
\hline PLoS Med & $7(0.9)$ \\
\hline \multicolumn{2}{|l|}{ Citations per journal $^{b}$} \\
\hline$B M J$ & $37,930(29.0)$ \\
\hline The Lancet & $34,911(26.7)$ \\
\hline JAMA & $25,273(19.3)$ \\
\hline Ann Intern Med & $13,381(10.2)$ \\
\hline Arch Intern Med & $11,945(9.1)$ \\
\hline New Engl J Med & $6,992(5.3)$ \\
\hline PLoS Med & $212(0.1)$ \\
\hline \multicolumn{2}{|c|}{ Articles per period of publication } \\
\hline 1985 to 1989 & $3(0.4)$ \\
\hline 1990 to 1994 & $53(7.2)$ \\
\hline 1995 to 1999 & $140(19.0)$ \\
\hline 2000 to 2004 & $166(22.6)$ \\
\hline 2005 to 2009 & $231(31.4)$ \\
\hline 2010 to 2012 & $143(19.4)$ \\
\hline \multicolumn{2}{|c|}{ Country of publication (first author) ${ }^{c}$} \\
\hline USA & $214(29.1)$ \\
\hline UK & $207(28.1)$ \\
\hline Canada & $94(12.8)$ \\
\hline Australia & $36(4.9)$ \\
\hline Switzerland & $26(3.5)$ \\
\hline France & $26(3.5)$ \\
\hline Denmark & $20(2.7)$ \\
\hline Italy & $20(2.7)$ \\
\hline
\end{tabular}

Number of authors per paper

$\begin{array}{ll}1 & 41(5.6) \\ 2 \text { to } 3 & 166(22.5) \\ 4 \text { to } 6 & 297(40.3) \\ >7 & 232(31.5)\end{array}$

aPLOS Medicine has been published weekly online since 19 October 2004. ${ }^{\mathrm{b}}$ Information refers to the total citations received by all the papers published in a given journal (for example, 289 papers published in BMJ received a total of 37,930 citations).

Information was incomplete for some records. We used country data of the first author in 704 out of 736 papers, while for 32 papers this information was retrieved from the correspondence address.

\section{Production and collaboration patterns}

Overall, 3,178 authors, 891 institutions and 51 countries worldwide were involved in the sample of articles. We identified 64 authors who published 5 or more papers (Table 2). The most prolific authors were Lau (15 papers), Guyatt (14), Peto (13), Yusuf (12), Cook (11) and Jüni (11). Many of the most prolific authors are affiliated with only a few academic institutions and/or medical centers; six are affiliated with the University of Oxford (Peto, Collins, Clarke, Baigent, Gray and Rothwell), five are affiliated with McMaster University (Guyatt, Yusuf, Cook, Douketis, and Eikelboom) and five are affiliated with the University of Bern and/or the Inselspital - Bern University Hospital (Jüni, Trelle, Egger, Reichenbach and Nüesch). Applying a threshold of 2 or more papers published as coauthors (Figures 2, 3, 4, 5, 6, 7), we identified 82 clusters of authors. Of these, 12 were identified as major coauthorship groups (1 with 55 members, 1 with 54 members, 1 with 27 members, 1 with 15 , 4 with 14 members, 3 with 11 members, 1 with 10 members, 1 with 8 members, 5 with 7 members, 5 with 6 members and 3 with 5 members).

Institutional productivity was headed by McMaster University (49 papers), University of Oxford (48 papers) and Harvard University (36 papers) (Table 3 ). Next came some of their affiliated hospitals or medical centers (Brigham and Women's Hospital and the Radcliffe Infirmary, with 32 and 30, respectively). Applying a collaboration threshold of at least 3 papers signed with inter-institutional collaboration, we identified 19 clusters comprising a total of 120 institutions (Figures 8 and 9). Of these, the most important institutional cluster comprised 76 members.

The productivity ranking for countries with respect to the number of papers (Table 4) was headed by the USA (310 papers), the UK (297 papers) and Canada (143 papers). After these countries came Australia (70 papers), and Italy and the Netherlands (57 papers each). The USA and the UK also headed the list of the number of different countries with which they had collaborated, as well as the total number of collaborations. Figure 10 shows a visual representation of the collaborative network between countries, in which we can see the relationships of some with respect to others and the position that each occupies in the network as a whole.

The 75 most cited articles by number of citations are listed in the supplementary material (see Additional file 2: 'List of most cited meta-analyses'). Heavily cited metaanalyses include randomized trials examining the health effects of pharmacological interventions in cardiology and oncology (for example, antithrombotic trials, anti-platelet trials, antihypertensive trials, lipid-lowering trials, chemotherapy for diverse cancers such as breast cancer, lung cancer, or head and neck cancers). 
Table 2 Ranking of most prolific authors (five or more papers) and their collaborative patterns

\begin{tabular}{|c|c|c|c|c|c|c|}
\hline Author & $\begin{array}{l}\text { Primary affiliation at } \\
\text { the time of publication }\end{array}$ & $\begin{array}{l}\text { Year of first } \\
\text { eligible paper }\end{array}$ & $\begin{array}{c}\text { Total } \\
\text { papers, } \mathrm{n}\end{array}$ & Signatures, $\mathrm{n}$ & Collaborations, $\mathrm{n}$ & $\begin{array}{l}\text { Main collaborators } \\
\text { (number of papers) }\end{array}$ \\
\hline Lau, Joseph & Brown University, USA & 1992 & 15 & 90 & 54 & $\begin{array}{c}\text { Chalmers TC and loannidis } \\
\text { JPA (5) }\end{array}$ \\
\hline Guyatt, Gordon H & $\begin{array}{l}\text { McMaster University, } \\
\text { Canada }\end{array}$ & 1996 & 14 & 104 & 76 & Cook DJ (5) \\
\hline Peto, Richard & University of Oxford, UK & 1991 & 13 & 124 & 75 & Collins R (8) \\
\hline Yusuf, Salim & $\begin{array}{l}\text { McMaster University, } \\
\text { Canada }\end{array}$ & 1989 & 12 & 83 & 54 & $\begin{array}{c}\text { Collins R, Eikelboom JW, Mehta } \\
\text { SR and Pogue J (3) }\end{array}$ \\
\hline Cook, Deborah J & $\begin{array}{l}\text { McMaster University, } \\
\text { Canada }\end{array}$ & 1995 & 11 & 71 & 49 & Guyatt GH (5) \\
\hline Jüni, Peter & $\begin{array}{l}\text { University of Bern, } \\
\text { Switzerland }\end{array}$ & 1996 & 11 & 124 & 59 & Reichenbach S (8) \\
\hline Collins, Rory & University of Oxford, UK & 1991 & 9 & 78 & 45 & Peto R (8) \\
\hline Trelle, Sven & $\begin{array}{l}\text { University of Bern, } \\
\text { Switzerland }\end{array}$ & 2007 & 9 & 103 & 67 & Jüni $P$ and Reichenbach S (7) \\
\hline Bucher, Heiner C & $\begin{array}{l}\text { University Hospital } \\
\text { Basel, Switzerland }\end{array}$ & 1996 & 8 & 60 & 41 & Guyatt GH (4) \\
\hline Egger, Mathias & $\begin{array}{l}\text { University of Bern, } \\
\text { Switzerland }\end{array}$ & 2001 & 8 & 65 & 49 & $\begin{array}{c}\text { Jüni } P \text {, Reichenbach } S \text { and } \\
\text { Trelle } S(3)\end{array}$ \\
\hline Gluud, Christian & $\begin{array}{l}\text { Copenhagen University } \\
\text { Hospital, Denmark }\end{array}$ & 2001 & 8 & 40 & 21 & Wetterslev J (3) \\
\hline Gøtzsche, Peter C & $\begin{array}{l}\text { The Nordic Cochrane } \\
\text { Centre, Denmark }\end{array}$ & 1995 & 8 & 27 & 17 & Johansen HK (3) \\
\hline Jackson, Jeffrey L & $\begin{array}{l}\text { Zablocki VA Medical } \\
\text { Center, USA }\end{array}$ & 1997 & 8 & 33 & 23 & $\begin{array}{c}\text { Browning } R \text { and O'Malley } \\
\text { Patrick G (2) }\end{array}$ \\
\hline Law, Malcolm R & $\begin{array}{l}\text { Queen Mary University } \\
\text { of London, UK }\end{array}$ & 1991 & 8 & 24 & 7 & Wald NJ (8) \\
\hline Reichenbach, Stephan & $\begin{array}{l}\text { University of Bern, } \\
\text { Switzerland }\end{array}$ & 2004 & 8 & 81 & 44 & Jüni $P(8)$ \\
\hline Sutton, Alex J & University of Leicester, UK & 2003 & 8 & 40 & 28 & Cooper NJ (3) \\
\hline Suttorp, Maarten J & $\begin{array}{l}\text { St Antonius Hospital, } \\
\text { the Netherlands }\end{array}$ & 2003 & 8 & 120 & 61 & $\begin{array}{c}\text { Maglione M, Mojica WA, Morton } \\
\text { SC and Shekelle PG (5) }\end{array}$ \\
\hline Wald, Nicholas J & $\begin{array}{l}\text { Queen Mary University } \\
\text { of London, UK }\end{array}$ & 1991 & 8 & 24 & 7 & Law MR (8) \\
\hline Clarke, Michael & University of Oxford, UK & 1994 & 7 & 83 & 67 & Peto R (4) \\
\hline Furberg, Curt D & $\begin{array}{l}\text { Wake Forest University } \\
\text { School of Medicine, USA }\end{array}$ & 1989 & 7 & 36 & 20 & $\begin{array}{l}\text { Loke YK, Psaty BM and } \\
\text { Singh S (3) }\end{array}$ \\
\hline Baigent, Colin & University of Oxford, UK & 1996 & 6 & 50 & 26 & Collins R and Peto R (5) \\
\hline Boersma, Eric & $\begin{array}{l}\text { Erasmus Medical Center, } \\
\text { the Netherlands }\end{array}$ & 2001 & 6 & 74 & 63 & $\begin{array}{l}\text { Califf RM, Serruys P, Simes J, } \\
\text { Simoons ML and Topol EJ (2) }\end{array}$ \\
\hline Boissel, Jean-Pierre & $\begin{array}{l}\text { Université Claude Bernard } \\
\text { Lyon 1, France }\end{array}$ & 1992 & 6 & 42 & 26 & Fagard RH and Gueyffier F (3) \\
\hline Chalmers, Thomas C & $\begin{array}{l}\text { Tufts Medical Center, } \\
\text { Tufts University, USA }\end{array}$ & 1990 & 6 & 31 & 16 & Lau J (5) \\
\hline Douketis, James D & $\begin{array}{l}\text { McMaster University, } \\
\text { Canada }\end{array}$ & 2000 & 6 & 32 & 25 & Crowther MA (2) \\
\hline Ebrahim, Shah & $\begin{array}{l}\text { London School of } \\
\text { Hygiene and Tropical } \\
\text { Medicine, UK }\end{array}$ & 1997 & 6 & 70 & 60 & Smith GD (4) \\
\hline loannidis, John PA & Stanford University, USA & 1995 & 6 & 32 & 17 & Lau J (5) \\
\hline Khan, Khalid S & $\begin{array}{l}\text { Queen Mary University } \\
\text { of London, UK }\end{array}$ & 1996 & 6 & 39 & 27 & $\begin{array}{c}\text { Bhattacharya S, Champaneria R, } \\
\text { Cooper K, Jolly K and Middleton } \\
\text { LJ (2) }\end{array}$ \\
\hline
\end{tabular}


Table 2 Ranking of most prolific authors (five or more papers) and their collaborative patterns (Continued)

\begin{tabular}{|c|c|c|c|c|c|c|}
\hline Klassen, Terry P & $\begin{array}{l}\text { University of Manitoba, } \\
\text { Canada }\end{array}$ & 1996 & 6 & 48 & 36 & Moher D (3) \\
\hline Loke, Yoon K & $\begin{array}{l}\text { University of East Anglia, } \\
\text { UK }\end{array}$ & 2000 & 6 & 18 & 7 & Singh S (4) \\
\hline McAlister, Finlay A & $\begin{array}{l}\text { University of Alberta, } \\
\text { Canada }\end{array}$ & 2001 & 6 & 30 & 23 & Armstrong PW (2) \\
\hline Moher, David & $\begin{array}{l}\text { Ottawa Hospital Research } \\
\text { Institute, Canada }\end{array}$ & 1996 & 6 & 52 & 42 & Klassen TP (3) \\
\hline Roberts, lan & $\begin{array}{l}\text { London School of } \\
\text { Hygiene and Tropical } \\
\text { Medicine, UK }\end{array}$ & 1996 & 6 & 18 & 12 & All co-authorship (1) \\
\hline Sattar, Naveed & $\begin{array}{l}\text { University of Glasgow, } \\
\text { UK }\end{array}$ & 2009 & 6 & 91 & 58 & Ray KK and Seshasai SRK (5) \\
\hline Shekelle, Paul G & Rand Corporation, USA & 2003 & 6 & 57 & 29 & $\begin{array}{c}\text { Maglione M, Mojica WA, Morton } \\
\text { SC and Suttorp MJ (5) }\end{array}$ \\
\hline Stone, Gregg W & $\begin{array}{l}\text { Columbia University } \\
\text { Medical Center, USA }\end{array}$ & 2005 & 6 & 120 & 77 & Leon MB (4) \\
\hline Tognoni, Gianni & $\begin{array}{l}\text { Consorzio Mario Negri } \\
\text { Sud, Italy }\end{array}$ & 1993 & 6 & 78 & 69 & $\begin{array}{l}\text { Marchioli R, Marfisi RM and } \\
\text { Roncaglioni MC (2) }\end{array}$ \\
\hline Topol, Eric J & $\begin{array}{l}\text { Scripps Translational } \\
\text { Science Institute, USA }\end{array}$ & 1991 & 6 & 44 & 33 & $\begin{array}{c}\text { Boersma E, Califf RM, Simoons } \\
\text { ML, Tcheng JE and Van de } \\
\text { Werf F (2) }\end{array}$ \\
\hline Bischoff Ferrari, Heike A & $\begin{array}{l}\text { University Hospital } \\
\text { Zurich, Switzerland }\end{array}$ & 2004 & 5 & 48 & 26 & $\begin{array}{c}\text { Dawson Hughes B, Staehelin } \\
\text { HB, Willett WC and Wong } \\
\text { JB (4) }\end{array}$ \\
\hline Briel, Matthias & $\begin{array}{l}\text { University Hospital } \\
\text { Basel, Switzerland }\end{array}$ & 2006 & 5 & 51 & 43 & Bucher HC (3) \\
\hline Eikelboom, John W & $\begin{array}{l}\text { McMaster University, } \\
\text { Canada }\end{array}$ & 2000 & 5 & 19 & 10 & Yusuf S (3) \\
\hline Ernst, Edzard & University of Exeter, UK & 1995 & 5 & 18 & 11 & White AR (3) \\
\hline Fagard, Robert H & $\begin{array}{l}\text { University of Leuven, } \\
\text { Belgium }\end{array}$ & 1997 & 5 & 51 & 36 & Boissel JP and Gueyffier F (3) \\
\hline Fergusson, Dean & $\begin{array}{l}\text { Ottawa Hospital Research } \\
\text { Institute, Canada }\end{array}$ & 1998 & 5 & 33 & 22 & Hutton B (3) \\
\hline Glasziou, Paul & Bond University, Australia & 1993 & 5 & 26 & 21 & All co-authorship (1) \\
\hline Godwin, Jon & $\begin{array}{l}\text { Glasgow Caledonian } \\
\text { University, UK }\end{array}$ & 1995 & 5 & 52 & 38 & Peto R (4) \\
\hline Gray, Richard & University of Oxford, UK & 2001 & 5 & 48 & 36 & Clarke $\mathrm{M}$ and Peto R (3) \\
\hline Hennekens, Charles H & $\begin{array}{l}\text { Florida Atlantic University, } \\
\text { USA }\end{array}$ & 1995 & 5 & 28 & 19 & Hebert, PR (4) \\
\hline Leibovici, Leonard & $\begin{array}{l}\text { Rabin Medical Center, } \\
\text { Israel }\end{array}$ & 2003 & 5 & 22 & 12 & Paul M (5) \\
\hline Maglione, Margaret & Rand Corporation, USA & 2003 & 5 & 49 & 22 & $\begin{array}{l}\text { Mojica WA, Morton SC, Shekelle } \\
\text { PG and Suttorp MJ (5) }\end{array}$ \\
\hline Mojica, Walter A & Rand Corporation, USA & 2003 & 5 & 49 & 22 & $\begin{array}{c}\text { Maglione M, Morton SC, Shekelle } \\
\text { PG, and Suttorp MJ (5) }\end{array}$ \\
\hline Morton, Sally C & $\begin{array}{l}\text { University of Pittsburgh, } \\
\text { USA }\end{array}$ & 2003 & 5 & 49 & 22 & $\begin{array}{c}\text { Maglione M, Mojica WA, Shekelle } \\
\text { PG and Suttorp MJ (5) }\end{array}$ \\
\hline Nüesch, Eveline & $\begin{array}{l}\text { University of Bern, } \\
\text { Switzerland }\end{array}$ & 2009 & 5 & 35 & 16 & Jüni $P(5)$ \\
\hline Paul, Mical & $\begin{array}{l}\text { Rabin Medical Center, } \\
\text { Beilinson Hospital, Israel }\end{array}$ & 2003 & 5 & 22 & 12 & Leibovici L (5) \\
\hline Pignon, Jean-Pierre & $\begin{array}{l}\text { Institut Gustave-Roussy, } \\
\text { France }\end{array}$ & 1999 & 5 & 53 & 46 & Bourhis J and Michiels S (2) \\
\hline
\end{tabular}


Table 2 Ranking of most prolific authors (five or more papers) and their collaborative patterns (Continued)

\begin{tabular}{|c|c|c|c|c|c|c|}
\hline Pocock, Stuart J & $\begin{array}{l}\text { London School of } \\
\text { Hygiene and Tropical } \\
\text { Medicine, UK }\end{array}$ & 1995 & 5 & 67 & 54 & $\begin{array}{l}\text { Boissel JP, Boutitie F, Fagard RH, } \\
\text { Gueyffier F, Hamm CW, Hueb WA, } \\
\text { King SB and Rodríguez A (2) }\end{array}$ \\
\hline Ray, Kausik K & $\begin{array}{l}\text { St George's University } \\
\text { of London, UK }\end{array}$ & 2009 & 5 & 73 & 49 & Saltar N and Seshasai SRK (5) \\
\hline Rothwell, Peter M & University of Oxford, UK & 2003 & 5 & 36 & 19 & Belch JFF and Meade TW (3) \\
\hline Seshasai, Sreenivasa RK & $\begin{array}{l}\text { University of Cambridge, } \\
\text { UK }\end{array}$ & 2009 & 5 & 73 & 49 & Ray KK and SN (5) \\
\hline Simes, John & $\begin{array}{l}\text { National Health and } \\
\text { Medical Research Council } \\
\text { Clinical Trials Centre, } \\
\text { Australia }\end{array}$ & 2002 & 5 & 53 & 36 & $\begin{array}{c}\text { Baigent C, Blackwell L, Collins R, } \\
\text { Keech A and Peto R (3) }\end{array}$ \\
\hline Smith, George Davey & University of Bristol, UK & 1993 & 5 & 63 & 54 & Ebrahim S (4) \\
\hline Torgerson, David J & University of York, UK & 1999 & 5 & 46 & 39 & $\begin{array}{c}\text { Adamson SJ and Bell Syer } \\
\text { SEM (2) }\end{array}$ \\
\hline Wetterslev, Jorn & $\begin{array}{l}\text { Copenhagen University } \\
\text { Hospital, Denmark }\end{array}$ & 2007 & 5 & 28 & 15 & Gluud C (3) \\
\hline Wilt, Timothy J & $\begin{array}{l}\text { Minneapolis VA Center } \\
\text { for Chronic Disease } \\
\text { Outcomes Research, } \\
\text { USA }\end{array}$ & 1998 & 5 & 40 & 32 & MacDonald R (4) \\
\hline
\end{tabular}

\section{Discussion}

Generally, the visibility and recognition of scientific research activities benefits from increasing collaborative research [18]. Research collaboration plays an important role in science, policy and medicine $[19,20]$. Research collaboration in the 'Big Science' era involves addressing important and relevant research questions that require a complex construction of multi-disciplinary teams of scientists and researchers, large-scale scientific structures, budgets of an unprecedented scale, and widespread sharing of scientific knowledge and data. Thus, meta-analysis can be considered a good example of 'Big Science' in medicine

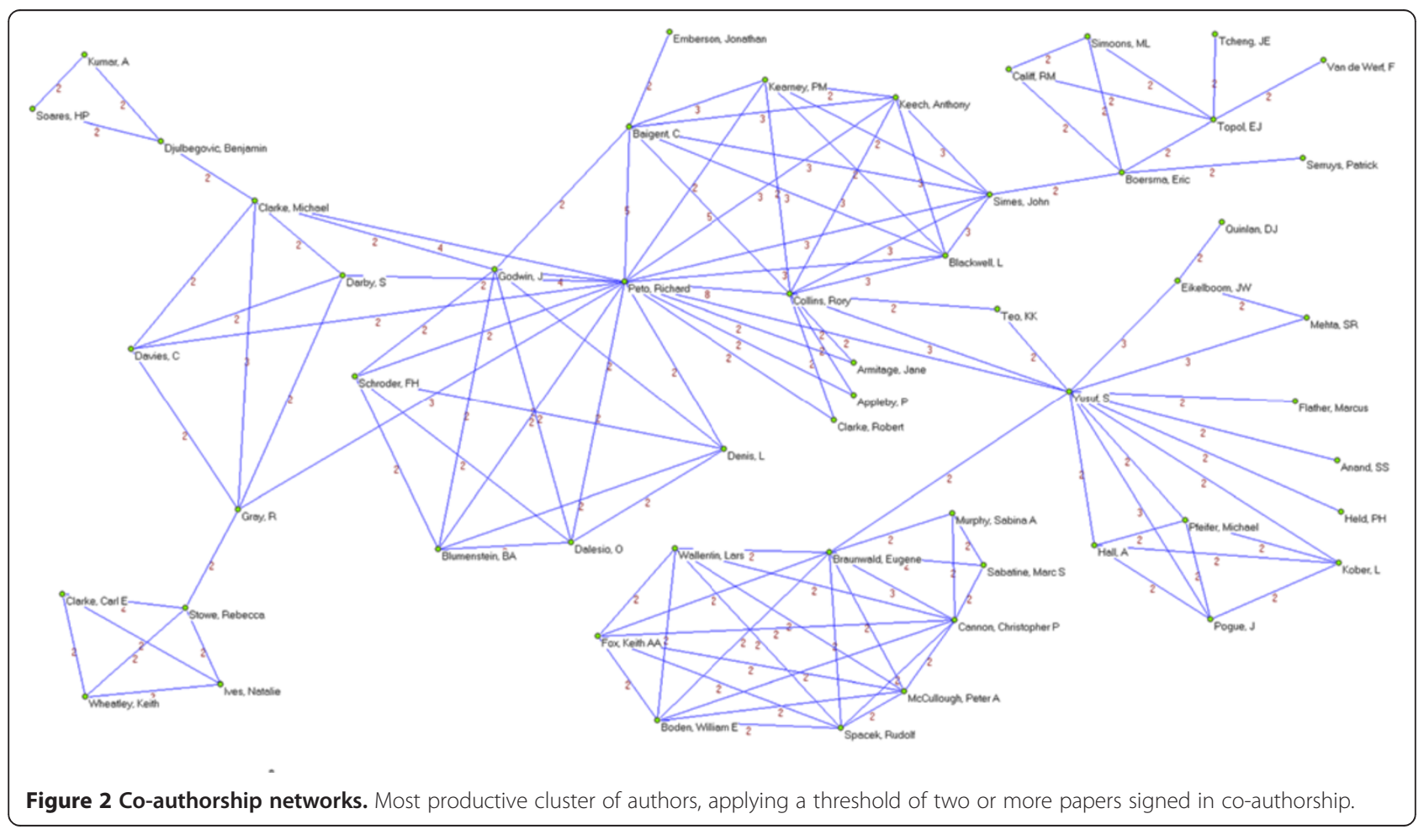




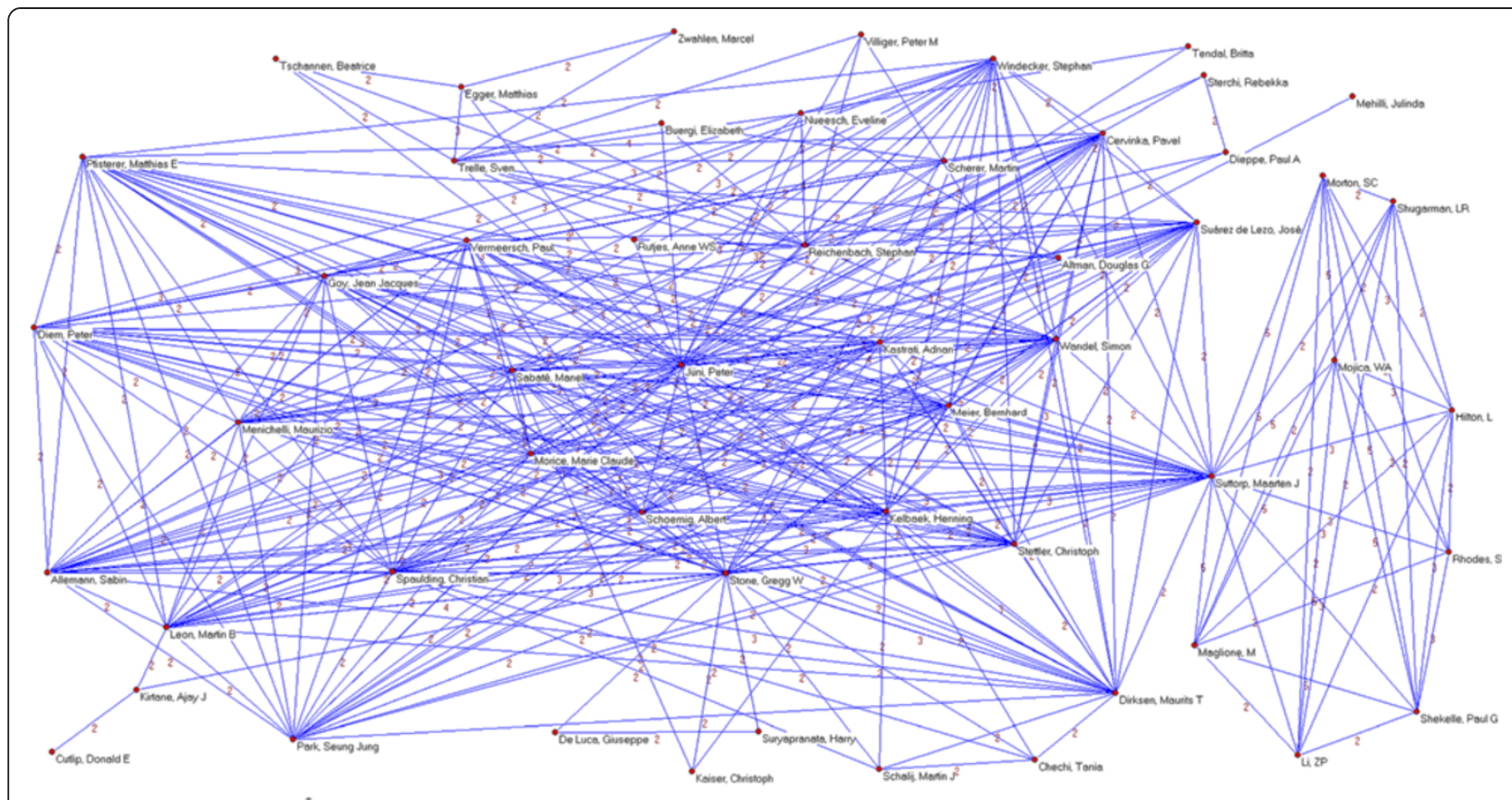

Figure 3 Co-authorship networks. Second most productive cluster of authors, applying a threshold of two or more papers signed in co-authorship.

and clinical epidemiology [21], as quantitative evidence synthesis is the application, in practice, of the principle that science is cumulative [22,23]. An obvious manifestation of this is the observed trend of 75 new randomized trials and 11 new systematic reviews being published daily, with a plateau in this growth not yet reached [24].
Therefore, promoting research collaboration in evidence synthesis is able to strengthen research activity, productivity and impact.

In general, we found a strong clustering of papers published in two British journals (BMJ and The Lancet accounted for $57 \%$ of meta-analyses), in contrast to other

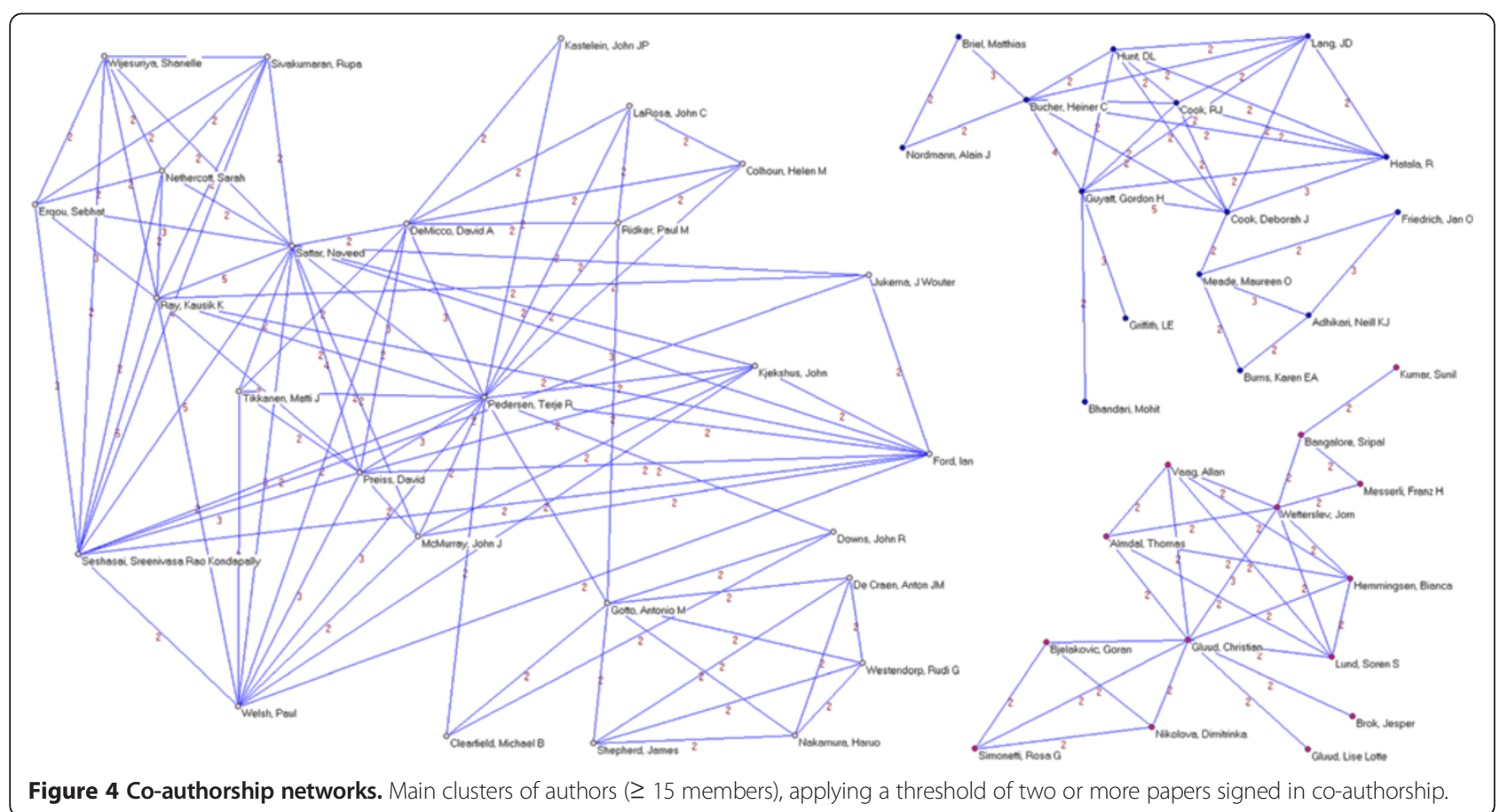




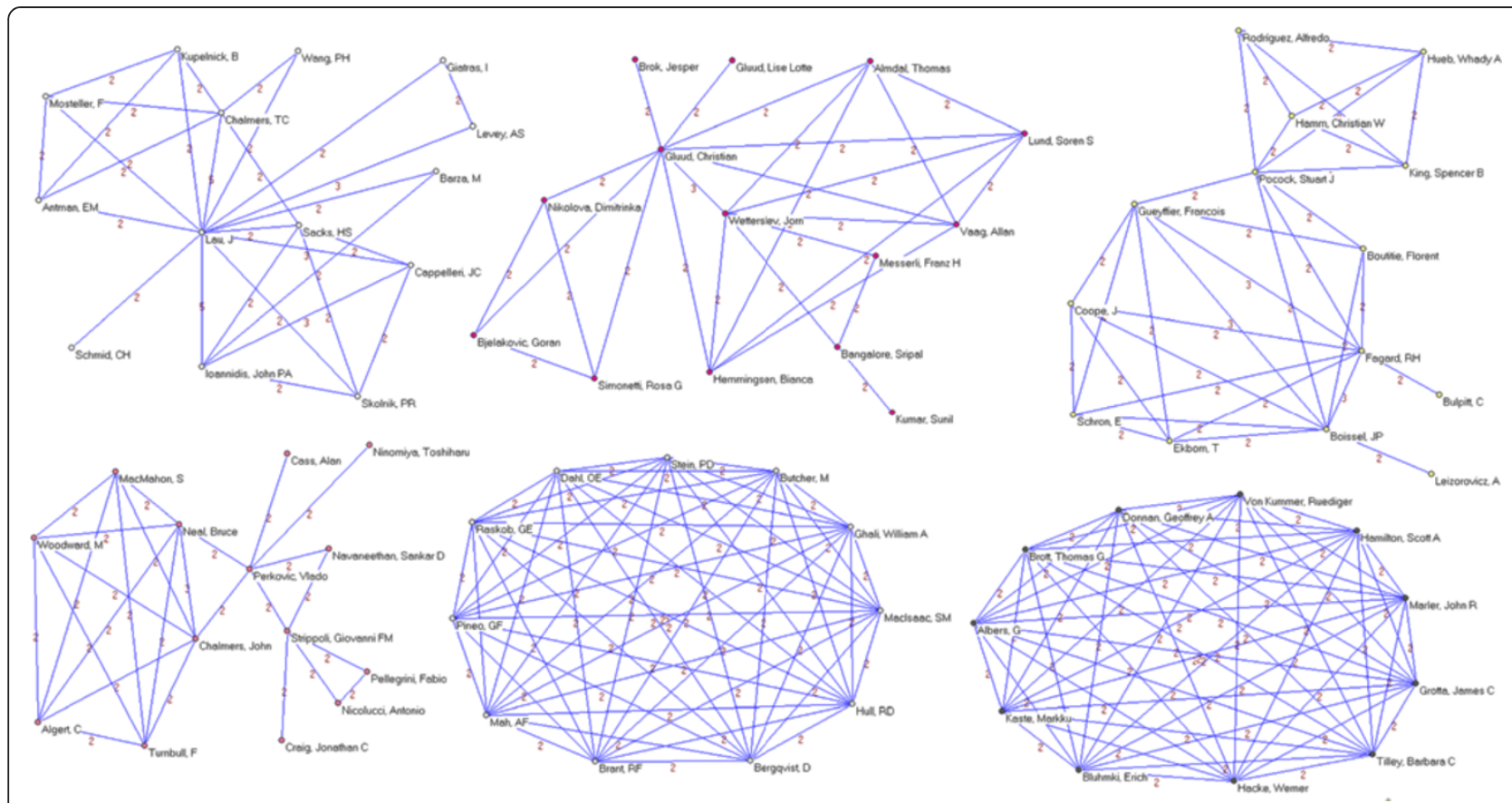

Figure 5 Co-authorship networks. Main clusters of authors ( $\leq 14$ members), applying a threshold of two or more papers signed in co-authorship.

general medical journals (for example, the NEJM represented less than $2 \%$ ). We hypothesized that these different findings between journals may potentially reflect an editorial policy and/or preference, with the BMJ, The Lancet and JAMA journals specifically being more interested in and/or promoting the publication of high-quality quantitative evidence synthesis.

Perhaps a relevant finding is that collaborative networks are expanding in multiple regions, revealing a discernable and well-established scientific community, with the most

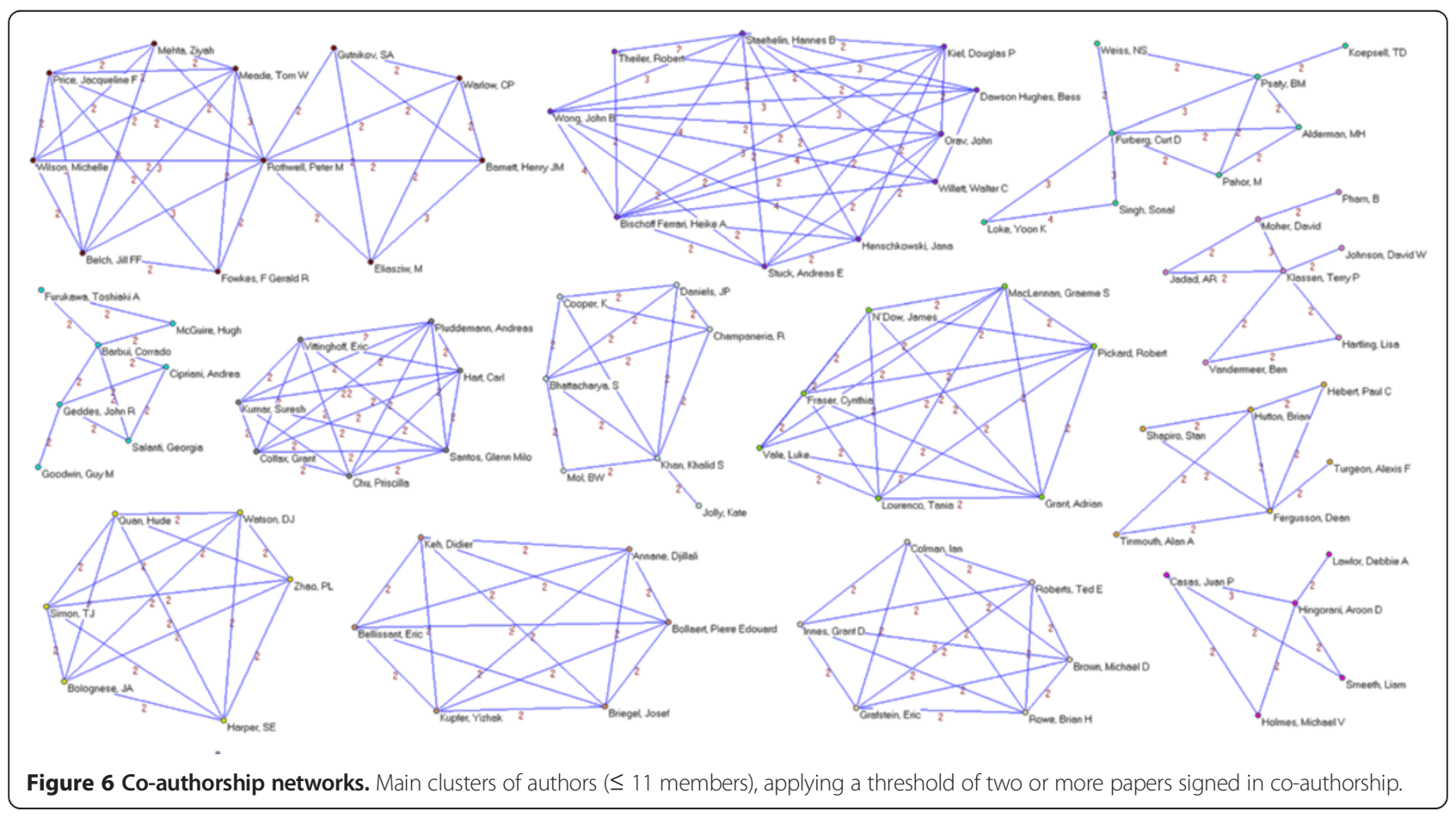




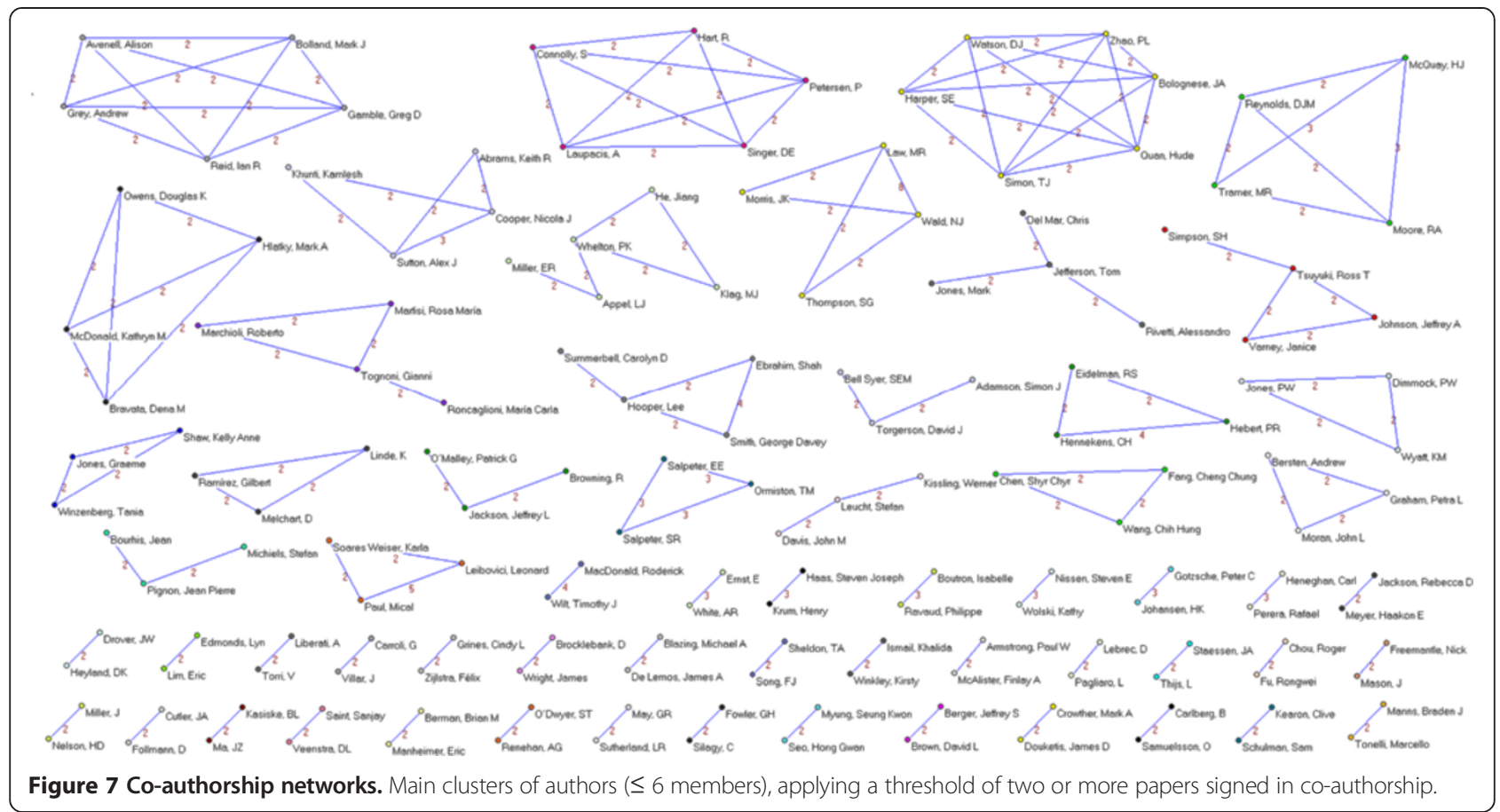

prolific authors and institutions having an important number of collaborations. As might be expected, the scientific community captured by the networks is centered on a nucleus of scientists and researchers from academia, medical centers and health research institutes from western high-income countries (North America, Western Europe and Australia/Oceania). Specifically, the most intense global collaborations took place between authors and institutions from the USA, the UK and Canada. However, although these three countries lead in the number of published high impact meta-analyses, the efforts during the period of study were global, with publications from authors and institutions in more than 50 different countries. Cultural links may have historically benefited some countries through alliances with nations and regions that speak the same language (as may be the case for the UK through alliances with Commonwealth countries that speak English) and have adopted similar scientific and research structures [25]. However, there is a clear over-representation of scientists based in western high-income countries, and the limited participation of low and middle incomebased researchers could warrant further pragmatic action. Given that research resources and funding are often restricted, it is the responsibility of the scientific community to utilize the resources available most efficiently when exploring research priorities to afford the health needs of the population, stimulating north-south and west-east collaborations where possible. In fact, these results are consistent with those reported by Uthman et al. [26], who assessed the characteristics of the 100 most frequently cited meta-analysis related articles. Although the scope of our research is definitely different from that paper, those authors also showed that the USA, the UK and Canada have taken leadership in the production of citation papers, but no first author from low or middle income countries led one of the most cited papers.

The maps of scientific partnership show that authors who are 'leaders' and thus who may contribute collaboration, have more frequent and intense collaboration between other authors and institutions from different countries. The study also identifies highly cohesive cluster networks and provides considerable information on the structure that can be put to various purposes, such as funding agencies designing strategies for future scientific collaboration, agencies such as the World Health Organization promoting a global coordinated agenda for perceived high priority clinical topics, and sharing of reliable and innovative methodologies that can be linked to world-class educational and training opportunities.

There are several possible explanations for our findings. The use of modern communication and information technologies, especially the Internet, has diminished the role of geographical and territorial boundaries in the access and transmissibility of information [27]. This has enabled scientists, and particularly systematic reviewers, closer internalization of research and collaboration. Similarly, the creation of some international collaborations, including those conducting clinical trials, may have settled the groundwork for the subsequent realization of collaborative meta-analyses that may have a clear scientific and clinical impact. For example, according to SCI-E, the most cited meta-analysis article has received more than 2,500 citations; 
Table 3 Ranking of most prolific institutions ( $\geq 10$ papers) and their collaborative patterns

\begin{tabular}{|c|c|c|c|c|c|c|c|}
\hline Institution, country & $\begin{array}{c}\text { Total } \\
\text { papers, } \mathrm{n}\end{array}$ & $\begin{array}{c}\text { Signatures, } \\
\mathrm{n}\end{array}$ & $\begin{array}{c}\text { Institutional } \\
\text { collaborations (with } \\
\text { different institutions), } \mathrm{n}\end{array}$ & $\begin{array}{l}\text { Institutional collaborations } \\
\text { in same country } \\
\text { (domestic institutions), } \mathrm{n}\end{array}$ & $\begin{array}{l}\text { Institutional } \\
\text { collaborations from } \\
\text { different countries, } \mathrm{n}\end{array}$ & $\begin{array}{l}\text { Main institutional collaborator } \\
\text { (number of papers) }\end{array}$ & $\begin{array}{l}\text { Different } \\
\text { collaborativ } \\
\text { countries, } n\end{array}$ \\
\hline $\begin{array}{c}\text { McMaster } \\
\text { University, Canada }\end{array}$ & 49 & 216 & 109 & 31 & 78 & University of Toronto, Canada (10) & 19 \\
\hline University of Oxford, UK & 48 & 226 & 123 & 39 & 84 & Radcliffe Infirmary, UK (13) & 20 \\
\hline Harvard University, USA & 36 & 210 & 104 & 47 & 57 & Brigham and Women's Hospital, USA (23) & 16 \\
\hline $\begin{array}{l}\text { Brigham and Women's } \\
\text { Hospital, USA }\end{array}$ & 32 & 207 & 102 & 46 & 56 & Harvard University, USA (23) & 17 \\
\hline Radcliffe Infirmary, UK & 30 & 96 & 46 & 14 & 32 & University of Oxford, UK (13) & 11 \\
\hline University of London, UK & 29 & 207 & 125 & 34 & 91 & $\begin{array}{l}\text { University of Bristol, UK; University of } \\
\text { Edinburgh, UK and University of Oxford, UK (5) }\end{array}$ & 22 \\
\hline $\begin{array}{l}\text { Copenhagen University } \\
\text { Hospital, Denmark }\end{array}$ & 28 & 169 & 93 & 8 & 85 & $\begin{array}{c}\text { Azienda Ospedaliera San Camillo-Forlanini, Italy; } \\
\text { Université Paris V - René Descartes, France } \\
\text { and University of Copenhagen, Denmark (4) }\end{array}$ & 20 \\
\hline $\begin{array}{l}\text { University of } \\
\text { Toronto, Canada }\end{array}$ & 27 & 123 & 55 & 23 & 32 & $\begin{array}{c}\text { McMaster University, Canada and Sunnybrook } \\
\text { Health Science Center, Canada (4) }\end{array}$ & 12 \\
\hline $\begin{array}{l}\text { University of } \\
\text { Sydney, Australia }\end{array}$ & 23 & 120 & 70 & 14 & 56 & $\begin{array}{l}\text { National Health and Medical } \\
\text { Research Council (NHMRC), Australia (6) }\end{array}$ & 15 \\
\hline $\begin{array}{l}\text { University of } \\
\text { Birmingham, UK }\end{array}$ & 22 & 80 & 51 & 26 & 25 & $\begin{array}{l}\text { Queen Mary, University of London, } \\
\text { UK and University of Aberdeen, UK }\end{array}$ & (3) 11 \\
\hline University of Bristol, UK & 22 & 141 & 96 & 33 & 63 & University of London, UK (5) & 21 \\
\hline $\begin{array}{l}\text { University of } \\
\text { Alberta, Canada }\end{array}$ & 20 & 94 & 57 & 14 & 43 & $\begin{array}{l}\text { Institute of Health Economics, Canada } \\
\text { and University of Calgary, Canada (4) }\end{array}$ & 15 \\
\hline $\begin{array}{l}\text { University College } \\
\text { London, UK }\end{array}$ & 19 & 123 & 88 & 33 & 55 & $\begin{array}{l}\text { London School of Hygiene \& Tropical } \\
\text { Medicine, UK and Royal Free Hospital, UK (4) }\end{array}$ & 20 \\
\hline $\begin{array}{l}\text { University Hospital } \\
\text { Basel, Switzerland }\end{array}$ & 18 & 185 & 113 & 9 & 104 & Inselspital, Switzerland (5) & 20 \\
\hline Mayo Clinic, USA & 18 & 157 & 130 & 35 & 95 & $\begin{array}{l}\text { University of Texas Medical } \\
\text { School at Houston, USA (3) }\end{array}$ & 23 \\
\hline University of Glasgow, UK & 17 & 124 & 85 & 32 & 53 & University of Cambridge, UK (4) & 14 \\
\hline $\begin{array}{l}\text { Erasmus MC University } \\
\text { Medical Center Rotterdam, } \\
\text { the Netherlands }\end{array}$ & 17 & 145 & 106 & 8 & 98 & $\begin{array}{l}\text { Duke Clinical Research Institute (DCRI), } \\
\text { USA and University of Sydney, Australia (3) }\end{array}$ & 23 \\
\hline Cleveland Clinic, UK & 16 & 75 & 51 & 11 & 40 & $\begin{array}{l}\text { Duke Clinical Research Institute (DCRI), } \\
\text { USA and University of Sydney, Australia (3) }\end{array}$ & 14 \\
\hline The University of York, UK & 16 & 64 & 44 & 26 & 18 & University of Leeds, UK (3) & 8 \\
\hline $\begin{array}{l}\text { University of } \\
\text { Bern, Switzerland }\end{array}$ & 16 & 128 & 72 & 8 & 64 & Inselspital, Switzerland (11) & 16 \\
\hline
\end{tabular}


Table 3 Ranking of most prolific institutions ( $\geq 10$ papers) and their collaborative patterns (Continued)

\begin{tabular}{|c|c|c|c|c|c|c|c|}
\hline $\begin{array}{l}\text { Medical Research Council's } \\
\text { Clinical Trials Unit, UK }\end{array}$ & 16 & 81 & 59 & 25 & 34 & University of Leicester, UK (3) & 14 \\
\hline $\begin{array}{l}\text { Johns Hopkins University, } \\
\text { USA }\end{array}$ & 15 & 58 & 42 & 18 & 24 & University Hospital Basel, Switzerland (2) & 11 \\
\hline $\begin{array}{l}\text { Instituto di Ricerche } \\
\text { Farmacologiche Mario } \\
\text { Negri, Italy }\end{array}$ & 15 & 85 & 63 & 9 & 54 & University of Sydney, Australia (3) & 14 \\
\hline $\begin{array}{l}\text { Hamilton Health } \\
\text { Sciences, Canada }\end{array}$ & 14 & 64 & 37 & 5 & 32 & McMaster University, Canada (9) & 11 \\
\hline $\begin{array}{l}\text { University of } \\
\text { Calgary, Canada }\end{array}$ & 14 & 62 & 35 & 17 & 18 & University of Alberta, Canada (4) & 10 \\
\hline Tufts University, USA & 14 & 79 & 45 & 14 & 31 & Tufts Medical Center, USA (6) & 13 \\
\hline $\begin{array}{l}\text { University of California, } \\
\text { San Francisco, USA }\end{array}$ & 14 & 77 & 56 & 24 & 32 & San Francisco VA Medical Center, USA (3) & 16 \\
\hline University of Aberdeen, UK & 13 & 73 & 50 & 25 & 25 & NHS Grampian, UK (5) & 11 \\
\hline $\begin{array}{l}\text { Sunnybrook Health Science } \\
\text { Center, Canada }\end{array}$ & 13 & 83 & 45 & 17 & 28 & University of Toronto, Canada (10) & 9 \\
\hline $\begin{array}{l}\text { University of Ottawa, } \\
\text { Canada }\end{array}$ & 13 & 70 & 40 & 16 & 24 & $\begin{array}{c}\text { Children's Hospital of Eastern Ontario, } \\
\text { Canada; McMaster University, Canada; Ottawa } \\
\text { Hospital Research Institute (OHRI), Canada; } \\
\text { University of Manitoba, Canada and University } \\
\text { of Toronto, Canada (3) }\end{array}$ & 13 \\
\hline $\begin{array}{l}\text { Wake Forest } \\
\text { University, USA }\end{array}$ & 12 & 55 & 31 & 17 & 14 & $\begin{array}{l}\text { University of East Anglia, UK and } \\
\text { University of Washington, USA (4) }\end{array}$ & 7 \\
\hline Inselspital, Switzerland & 12 & 119 & 67 & 8 & 59 & University of Bern, Switzerland (11) & 16 \\
\hline $\begin{array}{c}\text { University of } \\
\text { Washington, USA }\end{array}$ & 12 & 44 & 25 & 12 & 13 & $\begin{array}{l}\text { VA Puget Sound Health Care System, } \\
\text { USA and Wake Forest University, USA (4) }\end{array}$ & 8 \\
\hline University of Edinburgh, UK & 12 & 106 & 66 & 30 & 36 & University of London, UK (5) & 17 \\
\hline $\begin{array}{l}\text { Technical University } \\
\text { of Munich, Germany }\end{array}$ & 11 & 110 & 63 & 3 & 60 & $\begin{array}{l}\text { Columbia University Medical } \\
\text { Center (CUMC), USA (4) }\end{array}$ & 17 \\
\hline $\begin{array}{l}\text { Queen Mary, University } \\
\text { of London, UK }\end{array}$ & 11 & 46 & 31 & 8 & 23 & University of Birmingham, UK (3) & 9 \\
\hline Tufts Medical Center, USA & 11 & 41 & 16 & 8 & 8 & Tufts University, USA (6) & 3 \\
\hline $\begin{array}{l}\text { London School of } \\
\text { Hygiene \& Tropical } \\
\text { Medicine, UK }\end{array}$ & 11 & 106 & 86 & 15 & 71 & University College London, UK (4) & 25 \\
\hline $\begin{array}{l}\text { University of } \\
\text { Pittsburgh, USA }\end{array}$ & 11 & 64 & 51 & 16 & 35 & $\begin{array}{l}\text { Erasmus MC University Medical Center } \\
\text { Rotterdam, the Netherlands and } \\
\text { Ohio State University, USA (2) }\end{array}$ & 12 \\
\hline
\end{tabular}




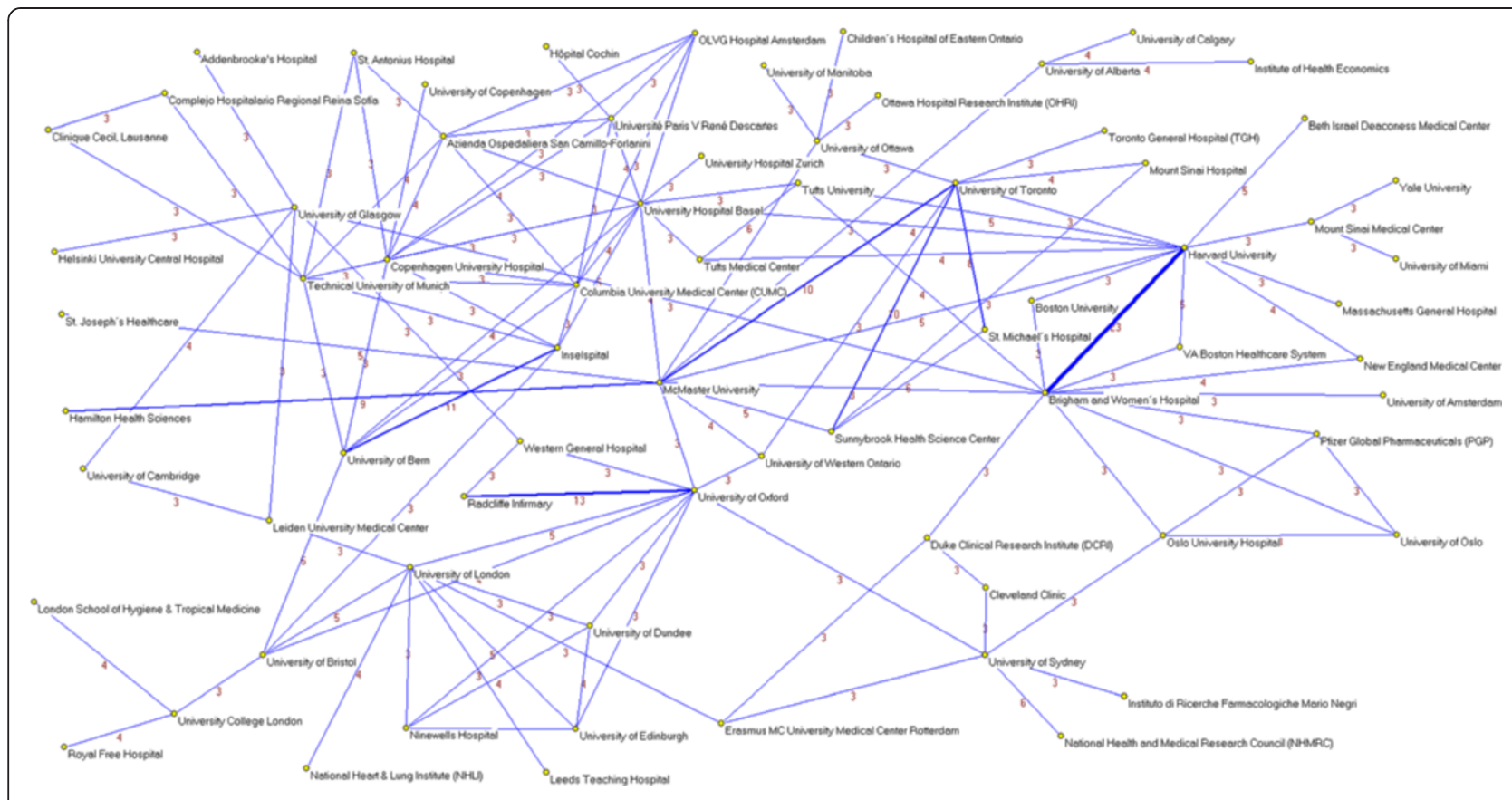

Figure 8 Institutional networks. Most productive cluster of institutions applying a threshold of three or more papers signed in co-authorship.

this was a paper by the Antithrombotic Trialists' Collaboration [28] that contributed to determine the protective effects of anti-platelet therapy (such as low dose aspirin) for patients at high risk of occlusive vascular events. Analyses of the Oxford-based Early Breast Cancer Trialists Collaborative Group (EBCTCG) provided breakthrough examples of complete pictures of the evidence on the long-term effects of various therapies on early breast cancer [29-31].

Collaborative networks, an important form of social network analysis, have been intensively studied in many scientific disciplines, including biology, physics, medicine and economics [13,16,32-36]. To our knowledge, no study has previously described and characterized the global

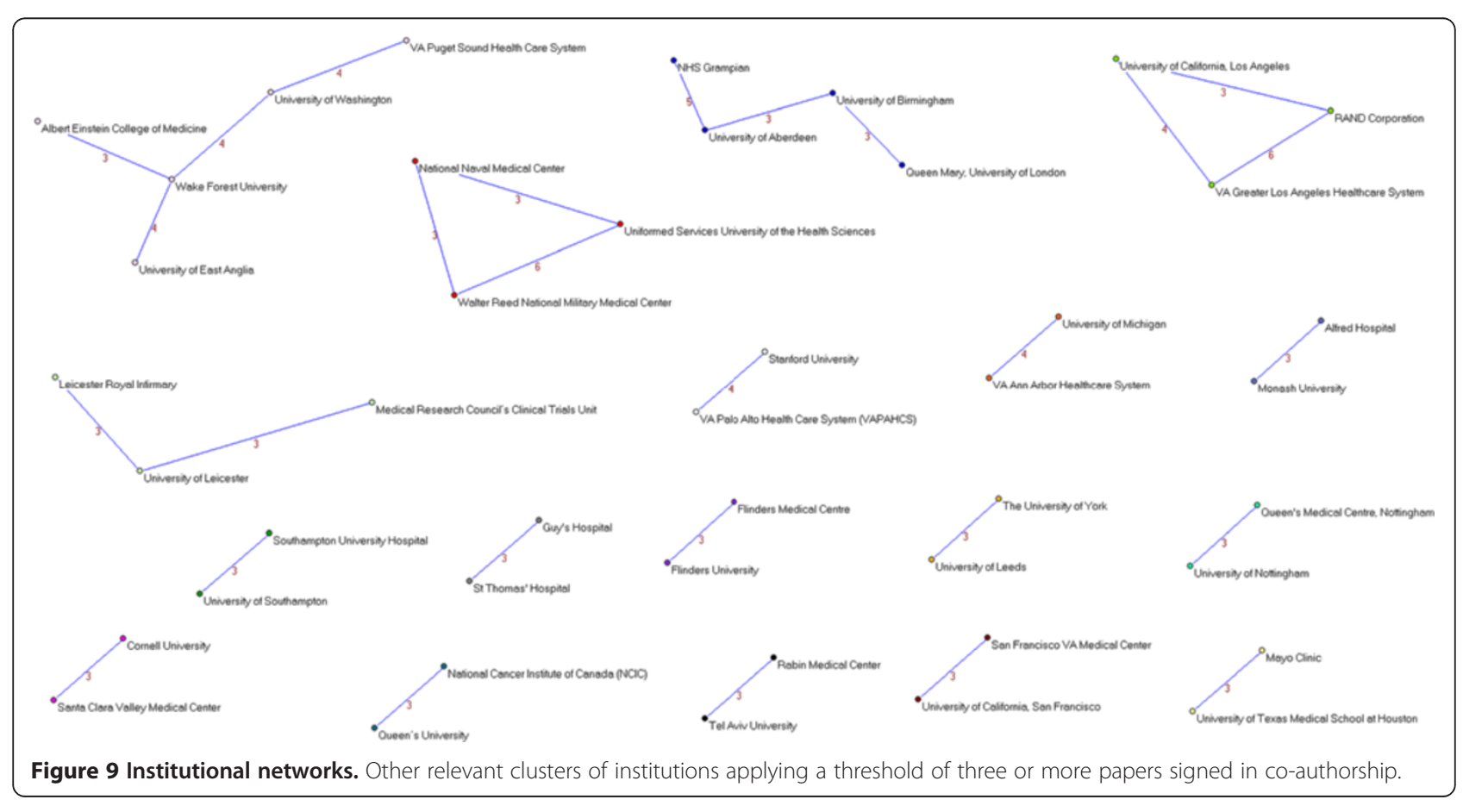


Table 4 Productivity and patterns of collaboration by countries

\begin{tabular}{|c|c|c|c|c|c|}
\hline Country & $\begin{array}{c}\text { Total } \\
\text { papers, } \mathrm{n}\end{array}$ & $\begin{array}{c}\text { Papers per million } \\
\text { inhabitants, } \mathrm{n}\end{array}$ & Collaborations, $\mathrm{n}$ & $\begin{array}{l}\text { Distinct countries } \\
\text { of collaborations, } n\end{array}$ & $\begin{array}{c}\text { Main collaborator(s) } \\
\text { (number of collaborations) }\end{array}$ \\
\hline USA & 310 & 0.99 & 428 & 43 & UK (63) \\
\hline UK & 297 & 4.73 & 380 & 44 & USA (69) \\
\hline Canada & 143 & 4.15 & 200 & 29 & USA (53) \\
\hline Australia & 70 & 3.14 & 165 & 30 & UK (30) \\
\hline Italy & 57 & 0.94 & 205 & 29 & USA (34) \\
\hline The Netherlands & 57 & 3.41 & 173 & 27 & USA (27) \\
\hline France & 51 & 0.78 & 159 & 27 & USA (26) \\
\hline Germany & 50 & 0.61 & 164 & 32 & USA (30) \\
\hline Switzerland & 47 & 5.94 & 177 & 35 & USA (25) \\
\hline Denmark & 41 & 7.36 & 124 & 28 & UK (18) \\
\hline Belgium & 23 & 2.09 & 92 & 23 & UK (14) \\
\hline Sweden & 21 & 2.22 & 69 & 14 & USA (13) \\
\hline Spain & 19 & 0.41 & 76 & 28 & USA (8) \\
\hline Norway & 14 & 2.83 & 56 & 20 & UK and USA (11) \\
\hline Japan & 13 & 0.10 & 51 & 21 & USA (9) \\
\hline New Zealand & 13 & 2.95 & 24 & 11 & UK (8) \\
\hline Finlad & 11 & 2.04 & 43 & 14 & Australia and USA (7) \\
\hline Brazil & 9 & 0.05 & 40 & 16 & UK and USA (5) \\
\hline Greece & 8 & 0.71 & 12 & 5 & UK and USA (4) \\
\hline Israel & 8 & 1.03 & 7 & 5 & USA (3) \\
\hline Ireland & 6 & 1.31 & 24 & 14 & UK (5) \\
\hline China & 6 & 0.00 & 10 & 7 & USA (4) \\
\hline South Africa & 6 & 0.12 & 23 & 16 & USA (4) \\
\hline Argentina & 5 & 0.12 & 24 & 13 & Brazil, Switzerland, UK and USA (3) \\
\hline Czech Republic & 5 & 0.48 & 42 & 18 & UK and USA (5) \\
\hline Poland & 5 & 0.13 & 23 & 13 & UK (4) \\
\hline South Korea & 5 & 0.10 & 31 & 13 & USA (4) \\
\hline Austria & 4 & 0.47 & 9 & 6 & Germany (3) \\
\hline Thailand & 4 & 0.06 & 10 & 10 & All countries (1) \\
\hline Chile & 3 & 0.17 & 10 & 8 & Canada and USA (2) \\
\hline India & 3 & 0.00 & 2 & 2 & Australia and UK (1) \\
\hline Portugal & 3 & 0.28 & 1 & 1 & Canada (1) \\
\hline Taiwan & 3 & 0.13 & 3 & 3 & Denmark, UK and USA (1) \\
\hline Costa Rica & 2 & 0.42 & 8 & 6 & Canada and USA (2) \\
\hline Hungary & 2 & 0.20 & 16 & 14 & UK and USA (2) \\
\hline Pakistan & 2 & 0.01 & 2 & 1 & UK (2) \\
\hline Russia & 2 & 0.01 & 18 & 14 & Belgium, Denmark, Germany, and UK (2) \\
\hline Saudi Arabia & 2 & 0.07 & 7 & 6 & UK (2) \\
\hline Serbia and Montenegro & 2 & 0.28 & 4 & 2 & Denmark and Italy (2) \\
\hline Turkey & 2 & 0.03 & 13 & 9 & Australia, Canada, Switzerland and USA (2) \\
\hline Colombia & 1 & 0.02 & 6 & 6 & All countries (1) \\
\hline Cuba & 1 & 0.09 & 5 & 5 & All countries (1) \\
\hline Gabon & 1 & 0.65 & 10 & 10 & All countries (1) \\
\hline
\end{tabular}


Table 4 Productivity and patterns of collaboration by countries (Continued)

\begin{tabular}{|c|c|c|c|c|c|}
\hline Ghana & 1 & 0.04 & 10 & 10 & All countries ( 1 ) \\
\hline Latvia & 1 & 0.49 & 12 & 12 & All countries ( 1 ) \\
\hline Mexico & 1 & 0.01 & 1 & 1 & USA (1) \\
\hline Morocco & 1 & 0.03 & 10 & 10 & All countries (1) \\
\hline Mozambique & 1 & 0.04 & 10 & 10 & All countries $(1)$ \\
\hline Republic of Malawi & 1 & 0.07 & 1 & 1 & UK (1) \\
\hline Singapore & 1 & 0.19 & 0 & 0 & - \\
\hline Tanzania & 1 & 0.02 & 10 & 10 & All countries (1) \\
\hline
\end{tabular}

Note: Country inhabitants (year 2011) were obtained from the World Bank.

collaborative patterns and networks of published metaanalyses of randomized trials. Very few studies have reviewed evidence synthesis for decision-making using a research collaboration approach $[35,36]$, and although not directly comparable with our analysis, there are aspects worthy of comment. A recent paper by Wagstaff and Culyer [35] examined four decades of health economics research. They compared authors, institutions, countries and journals in terms of the volume of publications in the US, the UK and Canada; Harvard University, the World Bank and the MIT emerged at the top on a variety of measures. Previously, Greenberg et al. [36] conducted a review of cost-effectiveness analyses of the English-language articles indexed in PubMed since 2006, and observed that the most prolific authors were affiliated with renowned US institutions in the USA (for example, Harvard University,
Stanford University and Tufts University, and their affiliated hospitals).

There are several limitations to our study. First, although the scientific production analysed has been drawn from an exhaustive analysis of the literature, it is possible that the search missed some relevant articles. Furthermore, some reports were published in journals without being indexed as meta-analyses, making them difficult to identify. The analyses inevitably represent an initial investigation, and a more detailed exploration is also needed. In addition, we restricted our analysis to meta-analyses that considered randomized trials as the primary source of clinical evidence, and therefore there may be scientists and researchers (or institutions) who do not appear because their papers are not reflected in the collaborative networks (for example, genetic epidemiology). It would be interesting to explore

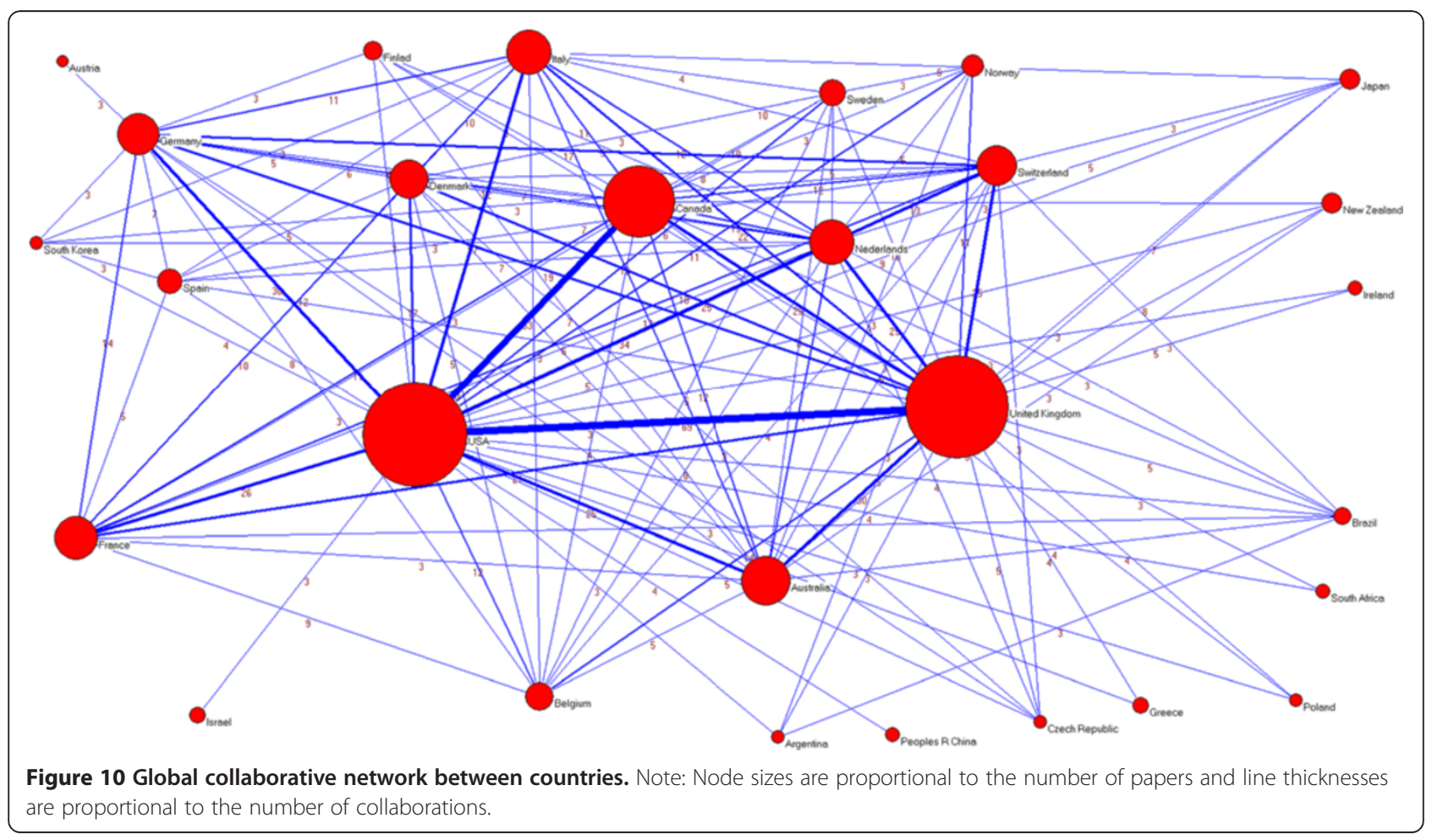


whether the use of alternative sources (such as observational research, descriptive epidemiology, molecular genetics, non-clinical studies) resulted in similar results to those reported here. Our analysis was also limited in scope, focusing only on original research and reviews articles. Undoubtedly, there are other important reports (for example, methodological [37-39] and conceptual papers $[6,40,41])$ that also merit consideration. Second, we excluded the Cochrane Library, specifically, the Cochrane Database of Systematic Reviews, a major source of systematic reviews. However, to date its impact factor is smaller than that of any of the included journals. Given the dynamic nature of the field, other opportunities for further research include examining the evolution of the identified networks over time (for example, by means of longitudinal analysis) also considering papers published in multi-disciplinary journals or those included in journals belonging to other categories.

Additionally, there were no further inquiries or attempts to verify the quality of reporting of the meta-analyses in our sample. Previous research [42] has addressed this issue, pointing out that some of the meta-analyses published in leading medical journals have important methodological limitations. Third, as in many bibliometric analyses, the importance of normalizing the names of scientists, researchers and their institutions is fundamental to avoiding potential errors caused in recognizing variations in the name of a single author. Nevertheless, we conducted a careful manual validation of the bibliographic references to avoid these potential errors. In the case of authors, the criterion followed with two or more variants of a name or surname was to check the coincidence of the different variants with the workplace. As discussed elsewhere [34], this procedure does not assure complete certainty. It does not take into account possible changes in the author's workplace, nor does it avoid the problem where the same bibliographic name refers to the scientific production of two or more authors, although the fact that a single field and a short chronologic period were being analyzed helped to minimize this kind of error. For institutional names, the main problem is that the same name frequently applies to two or more institutions, something that is common for authors who work in institutes or hospitals connected to universities. In such cases, we opted to assign as many names to the macroinstitutions as could be identified. Although this resulted in the problem of multiplying the number of institutions in the recount, it was necessary in order to avoid losing information concerning the macroinstitutions occurring in second place or later in the list of names. The same criterion of multiplying the names was used in the case of the institutes and other research organizations, sometimes administratively dependent on one macroinstitution, the result being that a 'fictitious' inter-institutional collaboration may have been obtained.

\section{Conclusions}

Our study identified the most significant collaborative networks of authors, institutions and countries publishing meta-analyses of randomized trials in high impact medical journals. This information may be used to strengthen scientific capacity for global collaboration and help to build a cooperative scientific agenda for future research of excellence in the field of clinical evidence synthesis in a manner similar to how some international clinical trial collaborations have developed. We hope that this analysis will be useful as policy makers, researchers and institutions look to the future.

\section{Additional files}

Additional file 1: Definitions of collaborative measurements.

Additional file 2: List of most cited meta-analyses.

\section{Competing interests}

The authors declare that they have no competing interest.

\section{Authors' contributions}

FC-L conceived the original idea. AA-A, RA-B and FC-L designed the study. $A A-A$ and $F C-L$ collected the data and performed the statistical analysis. FC-L and $\mathrm{AA}-\mathrm{A}$ take responsibility for the integrity of the data and the accuracy of the data analysis. DM, BH and FC-L interpreted the data. All authors wrote and/or critically revised the manuscript for important intellectual content. All authors approved the final version of the manuscript. FC-L is the guarantor.

Author's information

RA-B and DM are joint senior authors.

\section{Funding}

This study received no specific funding. DM is funded by a University Research Chair, University of Ottawa; and $\mathrm{BH}$ is a Canadian Institutes of Health Research DSEN (Drug Safety and Effectiveness Network) New Investigator.

\section{Author details}

'Division of Pharmacoepidemiology and Pharmacovigilance, Spanish Medicines and Healthcare Products Agency (AEMPS), Madrid, Spain.

${ }^{2}$ Fundación Instituto de Investigación en Servicios de Salud, Valencia, Spain. ${ }^{3}$ López Piñero Institute for the History of Medicine and Science (IHMC), Spanish National Research Council (CSIC) and University of Valencia, Valencia, Spain. ${ }^{4}$ Department of History of Science and Documentation, University of Valencia, Valencia, Spain. ${ }^{5}$ Clinical Epidemiology Program, Ottawa Hospital Research Institute (OHRI), Ottawa, ON, Canada.

Received: 24 October 2013 Accepted: 2 January 2014

Published: 29 January 2014

\section{References}

1. Evidence-Based Medicine Working Group: Evidence-based medicine. A new approach to teaching the practice of medicine. JAMA 1992, 268:2420-2425.

2. Sackett DL, Rosenberg WM, Gray JA, Haynes RB, Richardson WS: Evidence based medicine: what it is and what it isn't. BMJ 1996, 312:71-72.

3. Cochrane AL: Effectiveness and Efficiency. Random Reflections on Health Services. London: Nuffield Provincial Hospitals Trust; 1972.

4. Higgins JPT: Green S, editors: Cochrane Handbook for Systematic Reviews of Interventions. Chichester: Wiley; 2008.

5. Moher D, Cook DJ, Eastwood S, Olkin I, Rennie D, Stroup DF: Improving the quality of reports of meta-analyses of randomised controlled trials: the QUOROM statement. Quality of Reporting of Meta-analyses. Lancet 1999, 354:1896-1900. 
6. Moher D, Liberati A, Tetzlaff J, Altman DG, PRISMA Group: Preferred reporting items for systematic reviews and meta-analyses: the PRISMA statement. PLOS Med 2009, 6:e1000097.

7. Boekholt $\mathrm{P}$, Edler J, Cunningham P, Flanagan K, European Commision: Drivers of International collaboration in research. Luxembourg: Publications Office of the European Union; 2009.

8. Murray CJ, Vos T, Lozano R, Naghavi M, Flaxman AD, Michaud C, Ezzati M, Shibuya K, Salomon JA, Abdalla S, Aboyans V, Abraham J, Ackerman I, Aggarwal R, Ahn SY, Ali MK, Alvarado M, Anderson HR, Anderson LM, Andrews KG, Atkinson C, Baddour LM, Bahalim AN, Barker-Collo S, Barrero LH, Bartels DH, Basáñez MG, Baxter A, Bell ML, Benjamin EJ, et al: Disability-adjusted life years (DALYs) for 291 diseases and injuries in 21 regions, 1990-2010: a systematic analysis for the Global Burden of Disease Study 2010. Lancet 2012, 380:2197-2223.

9. Murray CJ, Lopez AD: Measuring the global burden of disease. N Engl J Med 2013, 369:448-457.

10. Concato J, Shah N, Horwitz Rl: Randomized, controlled trials, observational studies, and the hierarchy of research designs. N Engl J Med 2000, 342:1887-1892.

11. Davidoff F, Haynes B, Sackett D, Smith R: Evidence based medicine. BMJ 1995, 310:1085-1086.

12. Moher D, Tetzlaff J, Tricco AC, Sampson M, Altman DG: Epidemiology and reporting characteristics of systematic reviews. PLoS Med 2007, 4:e78.

13. Newman ME: Coauthorship networks and patterns of scientific collaboration. Proc Natl Acad Sci USA 2004, 101:5200-5205.

14. Greenberg SA: How citation distortions create unfounded authority: analysis of a citation network. BMJ 2009, 339:b2680.

15. Kappagoda S, loannidis JP: Neglected tropical diseases: survey and geometry of randomised evidence. BMJ 2012, 345:e6512.

16. Catalá-López F, Alonso-Arroyo A, Aleixandre-Benavent R, Ridao M, Bolaños M, García-Altés A, Sanfélix-Gimeno G, Peiró S: Coauthorship and institutional collaborations on cost-effectiveness analyses: a systematic network analysis. PLoS One 2012, 7:e38012.

17. Batagelj V, Mrvar A: Pajek 1.28. Program for large network analysis. Ljubljana: University of Ljubljana; 2010.

18. Glänzel W, Schubert A: Analyzing scientific networks through coauthorship. In Handbook of Quantitative Science and Technology Research: the Use of Publication and Patent Statistics in Studies of S\&T Systems. Edited by Moed HF, Glanzel W, Schmoch U. Dordrecht: Springer; 2005.

19. Adams J: Collaborations: The fourth age of research. Nature 2013, 497:557-560

20. Katz JS, Hicks D, Narin F, Hamilton K: International collaboration. Nature 1996, 38:16.

21. Davey Smith G: Big business, big science? Int J Epidemiol 2008, 37:1-3.

22. Chalmers I, Hedges LV, Cooper H: A brief history of research synthesis. Eval Health Prof 2002, 25:12-37.

23. Tricco AC, Tetzlaff J, Moher D: The art and science of knowledge synthesis. J Clin Epidemiol 2011, 64:11-20.

24. Bastian H, Glasziou P, Chalmers I: Seventy-five trials and eleven systematic reviews a day: how will we ever keep up? PLOS Med 2010, 7:e1000326.

25. Adams J: Collaborations: the rise of research networks. Nature 2012, 490:335-336.

26. Uthman OA, Okwundu Cl, Wiysonge CS, Young T, Clarke A: Citation classics in systematic reviews and meta-analyses: who wrote the top 100 most cited articles? PLoS One 2013, 8:e78517.

27. Pan RK, Kaski K, Fortunato S: World citation and collaboration networks: uncovering the role of geography in science. Sci Rep 2012, 2:902.

28. Antithrombotic Trialists' Collaboration: Collaborative meta-analysis of randomised trials of antiplatelet therapy for prevention of death, myocardial infarction, and stroke in high risk patients. BMJ 2002, 324:71-86.

29. Early Breast Cancer Trialists' Collaborative Group (EBCTCG): Effects of chemotherapy and hormonal therapy for early breast cancer on recurrence and 15-year survival: an overview of the randomised trials. Lancet 2005, 365:1687-1717.

30. Early Breast Cancer Trialists' Collaborative Group: Polychemotherapy for early breast cancer: an overview of the randomised trials. Lancet 1998, 352:930-942.

31. Early Breast Cancer Trialists' Collaborative Group: Effects of radiotherapy and surgery in early breast cancer. An overview of the randomized trials. N Engl J Med 1995, 333:1444-1455.
32. Martin T, Ball B, Karrer B, Newman ME: Coauthorship and citation patterns in the Physical Review. Phys Rev E Stat Nonlin Soft Matter Phys 2013, 88:012814.

33. Morel CM, Serruya SJ, Penna GO, Guimarães R: Co-authorship network analysis: a powerful tool for strategic planning of research, development and capacity building programs on neglected diseases. PLoS Negl Trop Dis 2009, 3:e501.

34. González-Alcaide G, Aleixandre-Benavent R, Navarro-Molina C, Valderrama-Zurián JC: Coauthorship networks and institutional collaboration patterns in reproductive biology. Fertil Steril 2008, 90:941-956.

35. Wagstaff A, Culyer AJ: Four decades of health economics through a bibliometric lens. J Health Econ 2012, 31:406-439.

36. Greenberg D, Rosen AB, Wacht O, Palmer J, Neumann PJ: A bibliometric review of cost-effectiveness analyses in the economic and medical literature: 1976-2006. Med Decis Making 2010, 30:320-327.

37. Higgins JP, Thompson SG, Deeks JJ, Altman DG: Measuring inconsistency in meta-analyses. BMJ 2003, 327:557-560

38. Sterne JA, Sutton AJ, Ioannidis JP, Terrin N, Jones DR, Lau J, Carpenter J, Rücker G, Harbord RM, Schmid CH, Terzlaff J, Deeks K, Deeks JJ, Peters J, Macaskill P, Schwarzer G, Duval S, Altman DG, Moher D, Higgins JP: Recommendations for examining and interpreting funnel plot asymmetry in meta-analyses of randomised controlled trials. BMJ 2011, 343:d4002.

39. Riley RD, Higgins JP, Deeks JJ: Interpretation of random effects metaanalyses. BMJ 2011, 342:d549.

40. Liberati A, Altman DG, Tetzlaff J, Mulrow C, Gøtzsche PC, loannidis JP, Clarke M, Devereaux PJ, Kleijnen J, Moher D: The PRISMA statement for reporting systematic reviews and meta-analyses of studies that evaluate health care interventions: explanation and elaboration. PLoS Med 2009, 6:e1000100

41. Mills EJ, loannidis JP, Thorlund K, Schünemann HJ, Puhan MA, Guyatt GH: How to use an article reporting a multiple treatment comparison meta-analysis. JAMA 2012, 308:1246-1253.

42. Gerber $S$, Tallon D, Trelle S, Schneider M, Jüni P, Egger M: Bibliographic study showed improving methodology of meta-analyses published in leading journals 1993-2002. J Clin Epidemiol 2007, 60:773-780.

doi:10.1186/1741-7015-12-15

Cite this article as: Catalá-López et al.: Global collaborative networks on meta-analyses of randomized trials published in high impact factor medical journals: a social network analysis. BMC Medicine 2014 12:15.

\section{Submit your next manuscript to BioMed Central and take full advantage of:}

- Convenient online submission

- Thorough peer review

- No space constraints or color figure charges

- Immediate publication on acceptance

- Inclusion in PubMed, CAS, Scopus and Google Scholar

- Research which is freely available for redistribution

Submit your manuscript at www.biomedcentral.com/submit
C) Biomed Central 